\title{
Влияние Reasil® Humic Health на переваримость и баланс питательных веществ у цыплят-бройлеров
}

Корсаков К.В., кандидат сельскохозяйственных наук, доцент

ФГБОУ ВО «Саратовский государственный аграрный университет им. Н.И. Вавилова»

Аннотация: Представлены результаты физиологического опыта на 4 группах иыплят-бройлеров (по 3 головы В группе, с 21 дня жизни) по определению влияния различных доз кормовой добавки Reasil ${ }^{\circledR}$ Humic Health на основе гуминовых веществ на переваримость питательных веществ рациона, усвояемость азота и аминокислот. Контрольная группа получала основной рацион без добавки; опытные группы 2-4 получали добавку в дозах 1,0; 1,5 и 2,0 г/кг комбикорма. Коэффициент переваримости сырой клетчатки в опытных группах 2-4 превышал уровень контроля соответственно на 4,92, 5,25 и 0,51\%; использование азота корма в опытных группах также превышало показатель контрольной группы соответственно на 0,35; 2,19 и 2,04\%. Наибольщая доступность аминокислот наблюдалась 83 опытной группе: разница с контролем по доступности критических аминокислот - лизин, метионин, иистинтцистеин - составила соответственно 4,23, 2,98 и 8,15\%. Доступность аминокислот во 2 и 4 опытной группах практически не отличалась от контроля. Улучшение переваримости и использования питательных веществ рациона 6 опытных группах отразилось на продуктивности бройлеров: среднесуточный прирост живой массы 6 опытных группах 2-4 превышал уровень контроля соответственно на 1,1; 5,5 и 3,2\%. Оптимальной оказалась дозировка добавки 1,5 г на 1 кг комбикорма.

Ключебые слова: кормление, кормовая добабка, гуминовые кислоты, цыплята-бройлеры, переваримость, усвояемость азота, аминокислоты.

Введение. Рост продуктивности сельскохозяйственной птицы приводит к возрастающей потребности в качественных рационах, что стимулирует, в свою очередь, интенсивный поиск новых питательных и биологически активных добавок, способствующих удовлетворить самые высокие современные требования к полноценности кормления. Достаточно активное внимание уделяется кормовым добавкам на основе гуминовых кислот, которые улучшают имму- нитет и усиливают сопротивляемость организма к заболеваниям, являются хорошими энтеросорбентами, обладают гепатопректорными свойствами, оказывают положительное влияние на продуктивные качества животных [1-10].

Цель наших исследований заключалась в изучении обменных процессов в организме цыплят-бройлеров под влиянием Reasil ${ }^{\oplus}$ Humic Health - сухой кормовой добавки, производимой ООО «Лайф Форс» на основе немо- дифицированных микропористых гуминовых кислот леонардита, с содержанием гуминовых кислот более $80,0 \%$ от сухого вещества.

Материал и методика исследований. Цыплят подбирали по методу аналогов с учетом кросса, возраста, состояния здоровья, живой массы. Для проведения опыта по определению переваримости питательных веществ из каждой группы были отобраны по 3 головы цыплят-бройлеров в возрасте 21 дня и размещены в специ- 


\begin{tabular}{|c|c|c|c|}
\hline Группа & Поголовье, гол. & $\begin{array}{c}\text { Продолжительность } \\
\text { опыта, дней }\end{array}$ & Условия кормления \\
\hline 1 - контрольная & 3 & 12 & ОР (основной рацион) \\
\hline 2 - опытная & 3 & 12 & $\begin{array}{c}\text { OP + Reasil }{ }^{\oplus} \text { Humic Health, } \\
\text { 1,0 г/кг комбикорма }\end{array}$ \\
\hline 3 - опытная & 3 & 12 & $\begin{array}{c}\text { OP + Reasil }{ }^{\oplus} \text { Humic Health, } \\
\text { 1,5 г/кг комбикорма }\end{array}$ \\
\hline 4 - опытная & 3 & 12 & $\begin{array}{c}\text { OP + Reasil }{ }^{\oplus} \text { Humic Health, } \\
2,0 \text { г/кг комбикорма }\end{array}$ \\
\hline
\end{tabular}

альныхклетках.

Условия содержания, фронт кормления и поения, параметры микроклимата в группах были одинаковыми и соответствовали рекомендациям ВНИТИП. Опыт проводили по следующей схеме (табл. 1).

Цыплята контрольной группы 1 получали в качестве основного рациона (ОР) полнорационный комбикорм ПК-6, который состоял из зерна кукурузы, пшеницы, экструдированной сои, жмыха подсолнечного, масла подсолнечного, мясокостной муки, монокальцийфосфата и премикса. Для цыплят опытных групп 2-4 в комбикорм дополнительно включали кормовую добавку Reasil ${ }^{\circledR}$ Humic Health в количестве 1,0, 1,5 и 2,0 г на 1 кг комбикорма соответственно. Питательность комбикорма ПК-6 представлена в табл. 2.

Физиологический опыт проводился в 2 этапа: 1 этап - 5 дней предварительного периода для приучения цыплят $\mathrm{K}$ условиям содержания и освобождения желудочно-кишечного тракта от предшествующего корма; 2 этап - 7 дней учетного периода, в который ежедневно учитывали количество циенты переваримости основных групп питательных веществ рациона, представленные в табл. 3 .

Установлено, что обогащение рациона бройлеров кормовой добавкой Reasil ${ }^{\circledast}$ Humic Health oказало положительное влияние на переваримость питательных веществ. Так, коэффициент переваримости клетчатки в опытных группах 2-4 превышал уровень контроля соответственно на 4,92 , 5,25 и $0,51 \%$.

Во 2 опытной группе, получавшей минимальное количество добавки гуминовых кислот, отмечалась тенденция к улучшению переваримости сухого и органического вещества, сырого жира. Коэффициенты переваримости протеина и БЭВ практически не отличались от контрольных значений.

Лучшими показателями отличались цыплята 3 опытной группы, получавшие с рационом 1,5 г добавки на 1 кг комбикорма. Они лучше, чем контрольные цыплята, переваривали сухое и органичес-

\begin{tabular}{lc}
\hline Таблица 2. Питательность комбикорма Пк-6, \% \\
\hline \multicolumn{1}{c}{ Показатель (\%) } \\
\hline Обменная энергия, ккал & Содержание \\
\hline Сырой протеин & 310 \\
\hline Сырая клетчатка & 20,0 \\
\hline Сырой жир & 6,0 \\
\hline Лизин & 5,0 \\
\hline Метионин & 1,2 \\
\hline Триптофан & 0,5 \\
\hline Треонин & 0,2 \\
\hline Кальций & 0,9 \\
\hline Фосфор & 1,0 \\
\hline
\end{tabular}

Таблица 3. Коэффициенты переваримости (\%) питательных веществ рационов цыплятами-бройлерами

\begin{tabular}{|lcccccc} 
Группа & $\begin{array}{c}\text { Сырой } \\
\text { протеин }\end{array}$ & $\begin{array}{c}\text { Сырой } \\
\text { жир }\end{array}$ & $\begin{array}{c}\text { Сырая } \\
\text { клетчатка }\end{array}$ & БЭв & $\begin{array}{c}\text { Сухое } \\
\text { вещество }\end{array}$ & $\begin{array}{c}\text { Органи- } \\
\text { ческое } \\
\text { вещество }\end{array}$ \\
\hline $1($ к) & $77,46 \pm 2,19$ & $86,24 \pm 4,03$ & $18,64 \pm 2,19$ & $91,67 \pm 4,40$ & $73,54 \pm 3,20$ & $75,38 \pm 3,51$ \\
\hline 2 & $78,40 \pm 3,22$ & $86,98 \pm 3,39$ & $23,19 \pm 3,20$ & $90,93 \pm 4,55$ & $73,74 \pm 2,19$ & $75,64 \pm 3,71$ \\
\hline 3 & $79,60 \pm 4,20$ & $87,47 \pm 3,64$ & $23,89 \pm 2,19$ & $90,30 \pm 4,17$ & $73,96 \pm 4,02$ & $75,72 \pm 3,44$ \\
\hline 4 & $79,56 \pm 3,73$ & $86,03 \pm 4,09$ & $19,15 \pm 3,00$ & $91,95 \pm 2,19$ & $73,89 \pm 3,55$ & $75,71 \pm 2,19$ \\
\hline
\end{tabular}




\begin{tabular}{|c|c|c|c|c|}
\hline \multirow{2}{*}{ Показатель } & \multicolumn{4}{|c|}{ Группа цыплят } \\
\hline & $1(\mathrm{k})$ & 2 & 3 & 4 \\
\hline \multicolumn{5}{|l|}{ Поступило азота } \\
\hline с рационом, r & $4,47 \pm 0,12$ & $4,47 \pm 0,17$ & $4,47 \pm 0,09$ & $4,51 \pm 0,12$ \\
\hline \multicolumn{5}{|l|}{ Выделено азота } \\
\hline в помете, r & $1,92 \pm 0,09$ & $1,95 \pm 0,11$ & $1,82 \pm 0,12$ & $1,84 \pm 0,09$ \\
\hline Усвоено азота, r & $2,56 \pm 0,08$ & $2,57 \pm 0,08$ & $2,65 \pm 0,10$ & $2,67 \pm 0,09$ \\
\hline $\begin{array}{l}\text { Использовано азс } \\
\text { в \% от принятого }\end{array}$ & $57,15 \pm 1,19$ & $57,50 \pm 1,16$ & $59,34 \pm 1,21$ & $59,19 \pm 1,20$ \\
\hline
\end{tabular}

кое вещество (соответственно на 0,42 и 0,34\%), сырой протеин (на $2,16 \%$ и сырой жир (на 1,23\%).

Переваримость питательных веществ в 4 опытной группе была выше, чем в контроле, но несколько уступала показателям 3 опытной группы по протеину, сырому жиру и сухому веществу.

Интенсивность обменных процессов оценивают по балансу и использованию азота организмом птицы. Баланс азота характеризует биологическую полноценность скармливаемых животным рационов и является показателем степени использования азотистых веществ корма. Результаты балансового опыта по обмену азота представлены в табл. 4.

Количество усвоенного за сутки азота в опытных группах 2-4 превышало показатель контрольной группы соответственно на 0,4; 3,5 и 4,2\%. Использование азота (от принятого с кормом) в опытных группах также превышало показатель контрольной группы соответственно на 0,$35 ; 2,19$ и 2,04\%.

Одним из критериев оценки качества рациона является доступность аминокислот к всасыванию в желудочно-кишечном тракте. Доступность аминокислот у цып-

лят-бройлеров определяли по разнице между аминокислотами, поступившими с кормом, и аминокислотами, выделенными с пометом. Доступность аминокислот (в процентах от принятых количеств) представлена в табл. 5.

Наибольшая доступность аминокислот наблюдалась в 3 опытной группе. Разница с контролем по доступности критических аминокислот, таких как лизин, метионин, цистин+цистеин составила соответственно 4,23, 2,98 и 8,15\%. Доступность аминокислот во 2 и 4 опытной группах практически не отличалась от контроля, а по лизину и метионину отмечалась тенденция к незначительному увеличению этих показателей.

Данные по переваримости и усвояемости питательных веществ вполне согласуются с продуктивностью бройлеров. Результаты взвешивания подопытной птицы показали, что среднесуточный прирост живой массы в опытных группах 24 превышал уровень контроля соответственно на 1, 1; 5,5 и 3,2\%.

Заключение. Таким образом, включение сухой кормовой добавки Reasil ${ }^{\circledast}$ Humic Health в рацион цыплят-бройлеров приводит к улучшению переваримости питательных веществ, повышает усвояемость азотистых веществ, доступность аминокислот и способствует увеличению интенсивности прироста живой массы бройле- 
ров. Наиболее оптимальной оказалась норма включения добавки 1,5 г на 1 кг комбикорма.

\section{Литература}

1. Андрианова Е.Н. Хелаты на основе гуминовых соединений в кормлении цыплят-бройлеров // Андрианова Е.Н., Егоров И.А., Шевяков А.Н. и др. // Птицеводство. - 2017. - № 11 . - С. 12-16.

2. Беркович А.М. Итоги и перспективы применения гуминовых препаратов в продуктивном животноводстве, коневодстве и птицеводстве // Сб. докл. конф. М., 2006. - С. 67

3. Корсаков К.В. Использование добавки на основе гуминовых кислот / К.В. Корсаков, А.А. Васильев, С.П. Москаленко, Л.А. Сивохина, М.Ю. Кузнецов // Птицеводство. - 2018. - № 5. - С. 22-25.

4. Корсаков К.В. Применение кормовых добавок с гуминовыми кислотами в птицеводстве / К.В. Корсаков, А.А. Васильев, С.П. Москаленко, М.Ю. Кузнецов, Л.А. Сивохина // Зоотехния. 2018. - № 4. - C. 11-13.

5. Korsakov K.V. Efficiency of using the Reasil Humic Vet feed additive in broiler chicken farming / K.V. Korsakov, A.A. Vasiliev, S.P. Moskalenko, L.A. Sivokhina, M.Y. Kuznetsov // Intl. J. Engin. Technol. - 2018. - V. 7. - P. 281283.

6. Лискун Н.К. Гумивал для повышения продуктивности и резистентности цыплят // Ветеринария. - 2007. - №4. C.11-12.

7. Степченко Л.М. Влияние гумата натрия на обмен веществ и резистентность высокопродуктивной птицы // Степченко Л.М., Жорина Л.В., Кравцова Л.В. // Науч. докл. высш. шк.: Биол. науки. - 1991 . - № 10 (334).
8. Arafat R.Y. Effect of dietary humic acid via drinking water on the performance and egg quality of commercial layers / R.Y. Arafat, S.H. Khan, G. Abbas, J. Iqbal // Am. J. Biol. Life Sci. - 2015. - V. 3, No 2. -P. 26-30.

9. Ozturk E. Effects of dietary humic substances on egg production and egg shell quality of hens after peak laying period / E. Ozturk, C. Isa, O. Nuh, E. Guray // Afric. J. Biotechnol. - 2009. - V. 8, No 6. - P. $1155-1159$.

10. Islam K.M.S. Humic acid substances in animal agriculture /K.M.S. Islam, A. Schuhmacher, J.M. Gropp // Pakistan J. Nutr. - 2005. - V. 4. - P. 126-134.

Для контакта с автором:

Корсаков Константин Вячеславович

E-mail:

korsakovkonstantin@gmail.com

The Effects of Humic Feed Additive Reasil@ Humic Health on the Digestibility and Availability of Dietary Nutrients in Broiler Chicks

Korsakov K.V.

Saratov State Agrarian University of N.I. Vavilov

Summary: The digestibility of dietary nutrients, nitrogen assimilation, and availability of dietary amino acids were studied in the physiological trial on 4 treatments of broiler chicks ( 3 birds per treatment, since 21 days of age) fed diets without supplementation (control treatment 1) and supplemented with 1000, 1500 and 2000 ppm of an additive Reasil ${ }^{\odot}$ Humic Health based on humic substances (experimental treatments 2, 3, and 4, respectively). Digestibility of crude fiber in treatments 2-4 was higher in compare to control by 4.92; 5.25 and 0.51\%, assimilation of dietary nitrogen higher by $0.35 ; 2.19$ and $2.04 \%$, respectively. The best availability of amino acids was found in treatment 3: the difference with control in the availability of limiting amino acids lysine, methionine, and cystin+cystein was 4.23; 2.98 and $8.15 \%$, respectively, while in treatments 2 and 4 the availability of amino acids was similar to control. These improvements in the digestion resulted in the increase in average daily weight gains in treatments 2-4 in compare to control by $1.1 ; 5.5$ and $3.2 \%$, respectively. The dose of the additive 1500 ppm was found optimal.

Key words: nutrition, feed additive, humic acids, broiler chicks, digestibility, nitrogen assimilation, amino acids. 